\title{
Erratum to: Spectrum of MRI features of ganglion and synovial cysts
}

\author{
Nelson Neto ${ }^{1} \cdot$ Pedro Nunnes $^{2}$
}

Published online: 8 April 2016

(C) The Author(s) 2016. This article is published with open access at Springerlink.com

\section{Erratum to: Insights Imaging}

\section{DOI 10.1007/s13244-016-0463-z}

Due to a transcription error, the teaching points were mistakenly excluded from this article.

Please find the teaching points below:

Teaching Points

- Ganglion and synovial cysts are frequently associated with osteoarthritis.

- A smooth, thin-walled, homogeneous cyst with a stalk connecting to the joint is typical.

- Thin septa and internal debris should not be misinterpreted as worrisome findings.

- Wall thickening and irregularity, hematic content and surrounding fluid suggest acute complication.

Open Access This article is distributed under the terms of the Creative Commons Attribution 4.0 International License (http:// creativecommons.org/licenses/by/4.0/), which permits unrestricted use, distribution, and reproduction in any medium, provided you give appropriate credit to the original author(s) and the source, provide a link to the Creative Commons license, and indicate if changes were made.

The online version of the original article can be found at http://dx.doi.org/ 10.1007/s13244-016-0463-z.

Nelson Neto

neto_nelson@hotmail.com

1 Radiology Department, Centro Hospitalar de Lisboa Ocidental, Lisbon, Portugal

2 Radiology Department, Hospital da Lapa, Porto, Portugal 